\title{
A CULTURE OF REACTION: CANADIAN REFUGEE POLICY IN AN ERA OF ENVIRONMENTAL MIGRATION
}

Eric Omeziri, BA, Concordia University, 2004; BA, Carleton University, 2002

\author{
A Major Research Paper \\ presented to Ryerson University \\ in partial fulfilment of the requirements for the degree of \\ Master of Arts \\ in the Program of \\ Immigration and Settlement Studies
}

Toronto, Ontario, Canada, 2011

(C Eric Omeziri 2011 


\section{Author's Declaration}

I hereby declare that I am the sole author of this major research paper.

I authorize Ryerson University to lend this paper to other institutions or individuals for the purpose of scholarly research.

Signa

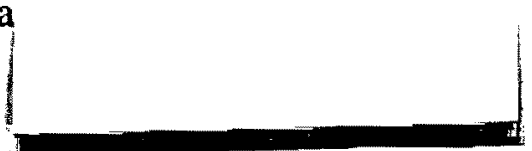

I further authorize Ryerson University to reproduce this paper by photocopying or by other means, in total or in part, at the request of other institutions or individuals for the purpose of scholarly research. 


\title{
A CULTURE OF REACTION: CANADIAN REFUGEE POLICY IN AN ERA OF ENVIRONMENTAL MIGRATION
}

\author{
Eric M. Omeziri \\ Master of Arts, 2011 \\ Immigration and Settlement Studies \\ Ryerson University
}

\begin{abstract}
In 2010, Forty-two million people worldwide were displaced from their homes due to environmental causes. These environmental migrants lack international recognition and have no recourse to the protections of the international refugee regime. This paper examines contradictions inherent in the environmental migration concept, and argues that state-level migration policies related to issues of environmental displacement are reactive and ad hoc in nature. Examining Canadian and US migration polices, this paper demonstrates that national governments have developed a "wait and see" approach towards environmental displacement. With a long history of responding to incidences of displacement, Canada is an important country in terms of its refugee resettlement policies. Accordingly, a review of Canadian refugee policy will provide insights relating to the policy response of western countries to future incidences of environmental displacement.
\end{abstract}

Keywords: environmental migrants; environment; migration policy; Canadian refugee policy; displacement 


\section{ACKNOWLEDGEMENTS}

This major research paper would not be possible were it not for the support of my supervisor Christopher Gore and Second Reader Myer Siemiatycki, whose guidance and encouragement were instrumental throughout the research and writing process. I would also like to express my deepest thanks to my friends and family who have stood by me unwaveringly during my course of study. 


\section{TABLE OF CONTENTS}

Introduction

An Era of Environmental Migration: Considering the Scope and Scale of Environmental

Displacement. 5

Environmental Refugees? Defining Environmental Migration. 12

Environment, Migration, Policy: Making the Connection. 16

International Recognition of Environmental Migrants. 17

Living in Uncertainty: Temporary Protected Status in the United States. 22

Special Measures: The Canadian Response to the 2010 Haitian Earthquake. 24

Refugee Policy in Canada. 29

Canadian Refugee Policy: Background Information. 31

Canadian Refugee Policy: Historical Precedents. 34 The Hungarian Refugee Crisis of 1956.

A Decade of Tumult: Refugee Crises during the 1970's - Chilean “Communists" \& Indochinese "Boat People".

Discussion.

Conclusion.

References. 45 


\section{LIST OF FIGURES}

Figure 1 Percentage of Displaced Persons in 2010: By Type of Hazard and by Continent.. 7

Figure 2 Canadian Refugee Admissions 1981-2009. 


\section{ABBREVIATIONS}

CIC - Citizenship and Immigration Canada

EDP - Environmentally displaced person

IDP - Internally displaced person

IOM - International Organization for Migration

IPCC - Intergovernmental Panel on Climate Change

$\mathrm{OB}$ - Operational Bulletin

TPS - Temporary Protected Status

TSR - Temporary Suspension of Removals

UNHCR - United Nations High Commissioner for Refugees

UNEP - United Nations Environment Programme

UNU - United Nations University 


\section{A CULTURE OF REACTION: CANADIAN REFUGEE POLICY IN AN ERA OF ENVIRONMENTAL MIGRATION}

\section{INTRODUCTION}

Tens of thousands of mostly poor people have died. Tens of millions have been temporarily or permanently displaced... We must, above all, shift from a culture of reaction to a culture of prevention. Kofi Annan - Former UN Secretary-General (1998)

Each year, humanitarian crises worldwide displace millions of people from places that once provided them with shelter, livelihood, and sense of community. With little time to plan and few resources at their disposal, individuals, families, or often entire villages must uproot themselves and at times cross international boundaries into neighbouring countries to seek asylum. If considered "refugees," as defined by the 1951 United Nations Convention Relating to the Status of Refugees (the Refugee Convention), these persons are offered a measure of protection. However, if the cause of their displacement is due to an advancing drought, natural disaster, or other environmentally related factor, displaced people in that situation may find that no guarantees of protection exist for them, and they may be faced with the possibility of being returned to confront a very uncertain future in a country they had once fled.

The large-scale human displacement caused by the First and Second World Wars led to the establishment of the Refugee Convention. The Convention attests to the high degree of international cooperation that existed during the immediate post-war period, and since coming into effect, the document has proved an effective legal instrument for offering protection to millions of Europeans forced to flee from their homelands. However, the displaced persons of today differ significantly from the post-war and early cold war refugees envisioned by those who established the Convention. Present-day cohorts of displaced persons are no longer 
predominantly European; rather, the majority of displaced persons originate from Asia, African, and Latin America (Myers, 2002; Warner, 2010; Yonetani, 2009). To a greater extent than previously, displaced persons requiring protection today seek entry into an asylum country as opposed to seeking legal status from a country within which they already reside. Displaced persons in the current context also differ from post-war refugees in that they are often forced to migrate for reasons that are unrelated to conflict, persecution or discrimination. Consequently, there are large groups of people that are ill-served or completely excluded from the protections offered by the current refugee protection regime. Global migration researcher Alexander Betts (2008), identifies three broad categories of people whose needs for protection are not being addressed due to gaps in the Convention:

a. People who may be considered as "neither/nor" groups, who flee desperate economic and social distress, resulting, for example, from state collapse and are in need of some form of subsidiary protection but are not 1951 Convention refugees.

b. People who flee natural disasters such as tsunamis, earthquakes and flooding, to whom UNHCR is increasingly providing protection but who have no clear legal status and for whom operational responses are ad hoc.

c. People who are displaced by causes related to environmental degradation or the consequences of climate change (p.2).

Categories $\mathrm{b}$ and $\mathrm{c}$ have displacement precipitated by a disruption to the natural environment in common. However, there are no generally agreed upon definitions for the environmentally induced forms of displacement described by Betts. Despite this, forms of migration that are caused by natural events are often referred to as cases of environmental migration.

A cursory investigation of the environmental migration concept leaves us with a set of contradictions. Although studied by a growing number of environmental scientists and migration experts, environmental migration remains ill defined while the processes that underlie occurrences of environmental migration are still poorly understood (see Black, 2001; Castles, 2002; Kibreab, 1998; Massey, Axinn and Ghimire, 2010). Driven by global issues such as 
climate change, urbanization, and conflict over scarce resources, environmental migration is nevertheless a context-specific phenomenon that defies generalization (Bates, 2002; Brown, 2007; Warner, 2009). Further, despite dire warnings and urgent recommendations from various parts of the international policy community, most national governments have not made significant advances in addressing the potentially far-reaching implications of large-scale displacement due to environmental degradation (Brown, 2008; Intergovernmental Panel on Climate Change, 1990; Myers, 2002).

This paper examines contradictions central to the environmental migration debate, and argues that state-level migration policy relating to environmentally induced displacement is currently reactive and ad hoc in nature. A review of Canada's refugee policy will demonstrate that national governments have developed a "wait and see" policy relating to issues of population displacement that is likely to remain in place for the foreseeable future. Canada is a significant destination country for refugee resettlement and an examination of its refugee policy will be instructive in determining current and future trends in the response of national governments to environmental displacement. Specific incidences of displacement and the subsequent policy response of the Canadian government will serve as illustrative examples of migration policy at work in circumstances of forced displacement. The review of those events will also be the context within which this paper will consider issues such as: why national governments intervene in certain cases of displacement and not others. Moreover, how domestic and international interests combine to shape migration policy at the state level.

North American governments respond to incidences of environmental displacement using temporary migration policy directives that provide relief to certain categories of displaced persons, but do not address the long-term challenges of environmental displacement or tackle its 
root causes. The current method of addressing environmental displacement has benefits, e.g. the added flexibility that ad hoc and temporary measures afford to governments when responding to crises. Still, the approach has its drawbacks, and at times results in piecemeal policy development that amounts to a "wait and see" approach to the issue of environmental migration. Governments' incorporate various economic, political, and social factors in their decisions regarding humanitarian intervention in cases of displacement. An examination of Canadian refugee policy reveals that the decision-making process does not occur in isolation from the many domestic and international interests that have a stake in international migration. A discussion of the decision-making process is particularly relevant to advocates of environmental migrants, who, like other public interests, have the ability to influence government and participate in the development of state-level responses to incidences of population displacement. This paper will begin with a discussion of environmental displacement internationally, examining recent assessments and predictions regarding the scope and scale of environmental displacement. The debate that surrounds the use of the "environmental refugee" concept will be reviewed, followed by a discussion that demonstrates the links between the natural environment, human migration, and migration policy. The effectiveness of specific, state-level, North American policies that address environmental displacement will be the subject of analysis before a historical review of refugee policy in Canada is conducted. Canada's humanitarian migration policies, past and present, have important implications for the future development of environmental migration policy. Those implications will be the subject of discussion at the conclusion of this paper. 


\section{AN ERA OF ENVIRONMENTAL MIGRATION: \\ CONSIDERING THE SCOPE AND SCALE OF ENVIRONMENTAL DISPLACEMENT}

All in all, the issue of environmental refugees promises to rank as one of the foremost human crises of our time. (Myers, 2001, p.3)

Environmental migration researcher Norman Myers is among those who predict that environmental catastrophes of unforeseen scale, affecting millions of people will occur in the near future if the effects of climate change and widespread environmental degradation are not rapidly addressed with bold policy measures. Myers' findings have been the subject of considerable debate (see Black, 2001; Kibreab, 1997), as estimates of environmentally induced displacement vary considerably; however, Myers' predictions serve as a valuable starting point for examining the potential scale of environmentally induced migration.

Myers estimates that in 1995 there were 25 million people displaced due to environmental causes (Myers, 1997). Many of the displaced are located in sub-Saharan Africa, the Sahel region in particular. However, Myers also lists parts of Asia and Latin America as regions where millions of individuals are displaced by changes to their environment. In 2010 an estimated 42 million people were displaced from their homes due to environmentally related causes (Yonetani, 2010); a figure that is roughly equal to the number of people displaced by war and persecution (UNHCR, 2010). By the year 2050, the total number of environmentally displaced persons is expected to reach 200 million, with some research indicating that the total number could be as high as 700 million (Warner, 2010).

The extraordinarily high estimates of environmental displacement are partly due to the wide variety of events that can trigger displacement. Even a small sampling of writings pertaining to the subject of environmental migration reveal that a sizeable number of 
environmental changes have the potential to cause large-scale population displacement. Soil erosion, rising sea-levels, desertification, deforestation, wild fires, earthquakes, land development (dam building in particular), volcanoes and industrial accidents are just some of the factors that have been cited (Bates, 2002; Castles, 2002; Myers, 2002; Yonetani, 2009). Climaterelated environmental disturbances figure prominently in estimates of displacement. In 2010 alone, 38.3 million people $-90 \%$ of all 2010 environmentally displaced persons (EDPs) - were forcibly displaced due to climate related causes such as droughts, floods, and storms (Yonetani, 2011). Figure 1 illustrates a categorization of displacement by type of hazard and region.

\section{FIGURE 1}

Percentage of Displaced Persons in 2010: By Type of Hazard and by Continent

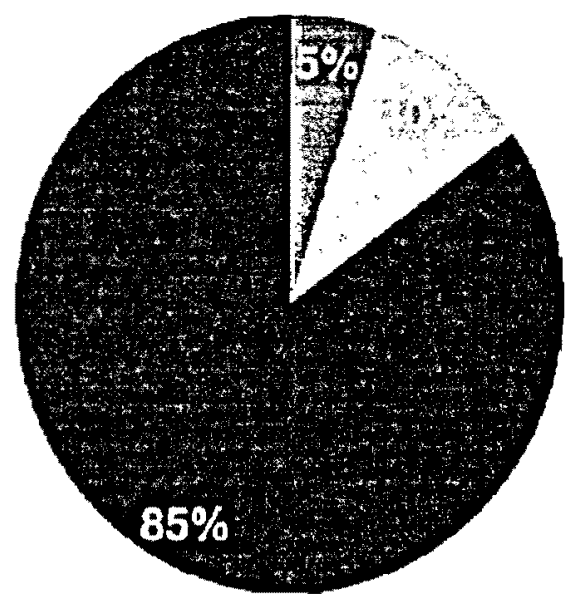

- Meteorological in Geophysical Hydrological

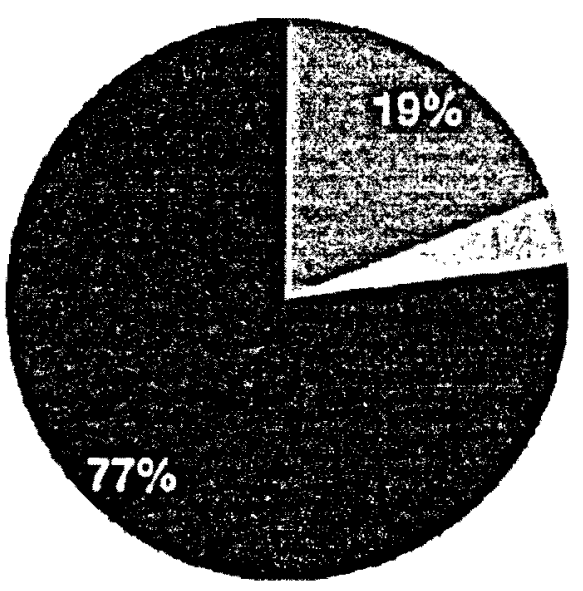

-Americas Africa - Asia

Source: Displacement due to Natural Disasters: Global Estimates for 2009 and 2010 (Yonetani, 2011, p.8)

Described as a "global phenomenon" (Yonetani 2010, p.6), environmental migration has the potential to affect a significant number of the Earth's inhabitants; and while it is true that the effects of environmental displacement are far-reaching, certain regions are especially vulnerable 
to environmentally induced population displacement. Factors such as a high population density, combined with a drought or flood prone climate, or proximity to a geographic risk factor such as an active fault line increase the risk of environmental displacement. Areas especially at risk for large-scale environmental migration are the Himalayan region of Asia, which may face severe water shortages due to glacial retreat, and the drylands of Central America where considerable vulnerability to both drought and severe weather in the form of hurricanes exists. The Nile, Ganges, and Mekong river delta regions are particularly at risk for major flooding, e.g. the flooding of large sections of Bangladesh that displaced thousands during the 2010 Monsoon season. In addition, the Sahel and Great Lakes regions of Africa are particularly at risk, and have experienced acute and gradual environmental declines leading to migrations as a result of droughts and intensive land degradation (Warner et al. 2009).

Research to better determine the extent of global environmental displacement is ongoing; nevertheless, current evidence supporting predictions of large-scale environmental migration is far from incontrovertible. The science of determining future environmental change, e.g. the rate at which sea-levels will rise or desertification due to climāte change will occur, is still in its nascent stages (Gillis, 2010), and as a result there are conflicting estimates régarding the number of people that may undergo some form of environmentally induced displacement. There are a myriad of often overlapping factors that influence people's migration decisions; therefore, isolating the environment as the underlying cause is an exceptionally difficult task. Underscoring the challenges of predicting environmental displacement, a recent report suggests that the United Nations Environment Programme (UNEP), an organization at the forefront of environmental migration policy, retracted its support of a much-quoted estimate that predicted 50 million environmental migrants by the year 2010 . The retraction was a response to evidence 
demonstrating that the population in certain areas listed as threatened by environmental degradation was actually increasing, as opposed to decreasing due to displacement (Bojanowski, 2011). There is further disagreement amongst researchers regarding the characterization of environmental migration as a problem requiring intervention. Richard Black (2001), a critic of the more alarming predictions relating to environmental displacement, notes that migration is only one strategy among many used by individuals to respond to environmental degradation. Discussing environmental changes on the African continent, Black describes "[environmental] migration as an essential part of the economic and social structure of the region, rather than a response to environmental decline" (Black, 2001, p.6), Black's observations are particularly relevant to circumstances that are on the voluntary end of the voluntary/involuntary spectrum of environmental migration decisions. In "voluntary" circumstances, individuals or families may engage in migration that is temporary, cyclical, or partial, e.g. where only one member of the family leaves the area of residence. These forms of migration may be reactions to a deterioration of the environment, however the net effect may result in improved livelihood outcomes for those $=$ affected, e.g. though the sending of remittances, or a reduced dependence on subsistence agriculture.

Despite the controversy that accompanies much of the discussion regarding environmental migration, several experts agree that the environment is a significant, although not always a direct (causal) factor, in migration decisions. That is to say, although the condition of natural environment is rarely the only factor provoking human migration, it is often a significant point of consideration in people's decisions to migrate. Bardsley and Hugo (2010) describe migration events as occurring on a continuum, where on one end of the continuum the environment is "not an important factor" and on the other, the environment is a "key factor." Following a period of 
heavy rains in the Jigawa state of northern Nigeria in 2010 , Nigerian authorities "indiscriminately" opened the gates of the Challawa and Tiga dams, flooding thousands of villages and displacing an estimated 2 million people (Associated Press, September 24, 2010). Northern Nigeria is prone to flooding due to intense seasonal rains; however, the risk of displacement due to flooding was compounded by anthropogenic factors such as the mismanagement of the dams, an underdeveloped infrastructure, and poor town planning (Yonetani, 2011). Like the Nigerian flood, most cases of environmentally induced displacement fall somewhere in the middle of Bardsley and Hugo's continuum where a complex interaction of environmental and anthropogenic factors are at work in causing people to relocate. Thus, policymakers who attempt to address the issue of environmentally induced migration must navigate a range of environmental, social, and political factors that have the potential individually or collectively cause displacement.

In a 2010 study of Nepalese out-migration and its relationship to environmental decline in the region, migration researchers Massey, Axinn, and Ghimire (2010), explore the connections between the environment and human population movements. Massey et al. base their findings on data obtained from an earlier study, known as the Chitwan Valley Family Study (CVFS), which used ethnographic and survey methods to collect information such as household composition data, in-depth life histories, land use patterns, and details of demographic events. Using the data contained within the CVFS, Massey et al. conducted an analysis of the migration patterns of Chitwan Valley residents. Their research focused on environmentally induced migration while controlling for variables that are more typically associated with migration, e.g. gender, ethnicity, income, and socio-economic status. Population density, perceptions of agricultural productivity, access to locally important natural resources, and land use patterns were identified as the 
predominant environmental conditions affecting migration in the region. Interestingly, the study found that perceptions of agricultural productivity were more predictive of environmental migration than actual decreases in productivity. In fact, Massey et al. demonstrated that the perception of agricultural decline was the most predictive factor related to identifying which inhabitants of the Chitwan Valley would relocate. From a policy standpoint, the finding has important implications regarding the need to address rural people's perceptions of the environment in relation to agriculture, in addition to dealing with substantive environmental issues such as natural resource management and sustainable land use. Policies that actively involve local peoples and address their particular concerns regarding changes to the environment are likely to be more effective at reconnecting people from rural areas with the land and reversing a trend of rural out-migration than top-down approaches.

Although the condition of the natural environment is an important factor in migrant decision-making in Nepal, Massey et al. (2010) found that the environment was superseded by factors such as human capital (skills, experiences, and abilities that raise an individual's productivity in the labour force), or social capital (the instrumental value that people derive from their social connections to others). Furthermore, the strength of the relationship between the condition (or perceived condition) of the environment and a decision to migrate was shown to be highly dependent upon the distances involved in the move. Shorter moves, e.g. to a neighbouring village, were more closely related to the health of the environment than long distance moves. Global migration spurred on by environmental damage does occur, though "for the most part, environmental deterioration appears to promote local searches for organic inputs or alternative employment opportunities, not a desperate search for relief in distant lands" (Massey et al. 2010, p.132). These findings are consistent with much of the research on environmental migration, 
which supports the idea that environmentally induced migration is, at this time, predominantly a local phenomenon, which is highly related to the social and economic factors that exist within the given context. The localized nature of environmental migration is a significant observation within Massey, Axinn, and Ghimire's research and reinforces the need for environmental migration policy that applies to specific populations within defined contexts. Thus, from a policy perspective, developing responses that take a bottom-up approach - beginning at the local level and obtaining input from involved stakeholders - is likely an effective strategy for addressing out-migration due to environmental degradation.

Massey et al.'s examination of Nepalese out-migration is instructive, yet a wider application for their findings could be achieved by connecting the research to a coherent and broadly accepted definition of what constitutes environmental migration and its causes. Consensus on how to define environmental migration has yet to be reached, and as a result, the lack of an agreed-upon definition may pose a challenge to ensuring that researchers are in fact studying the same phenomena and producing findings that can have relevance in different contexts. Some attempts to define environmental migration have had a certain measure of success, yet the definitions lack international recognition and remain contentious. The following discussion will examine some of the issues surrounding efforts to better define and classify environmental migration. The term "environmental refugee" will be a central focus of discussion, and the issues raised will further delineate the definition of environmental migration and serve as the basis for further exploration of the concept. 


\section{ENVIRONMENTAL REFUGEES? DEFINING ENVIRONMENTAL MIGRATION}

Considerable effort has been devoted to developing a definition of environmental migration that can gain international recognition and encompass the range of environmentally induced circumstances that lead to displacement. United Nations Environment Programme (UNEP) researcher Essam El-Hinnawi is often credited with first attributing the term "environmental refugee" to individuals who have been displaced due to environmental causes. In 1985, ElHinnawi described environmental refugees as:

...Those people who have been forced to leave their traditional habitat, temporarily or permanently, because of a marked environmental disnuption (natural and/or triggered by people) that jeopardized their existence and/or seriously affected the quality of their life. By 'environmental disruption' in this definition is meant any physical, chemical, and/or biological changes in the ecosystem (or resource base) that render it, temporarily or permanently, unsuitable to support human life. (El-Hinnawi, 1985, p. 4)

The term "environmental refugee" has since become popularized, perhaps owing to the term's ability to draw parallels between the more familiar circumstances of political refugees fleeing persecution and the plight of individuals displaced due to some form of degradation to their natural environment. "Environmental refugees" evokes images of people fleeing devastation due to a natural disaster or other form of environmental catastrophe and it is perhaps for that reason that the term has gained currency in the media and the wider public consciousness. From a policy standpoint the association of environmental migrants with conventional refugees might allow environmental migrants to benefit from the same kinds of protections offered by the international refugee protection regime already in place. However, in practice this has not occurred. Despite initial attempts to better define the environmental refugee concept, the terminology remains contentious, and there continues to be no widespread agreement on how to classify people displaced due to changes in their environment. 
There are several reasons for the indefiniteness of the environmental refugee concept. Firstly, the term "refugee" carries with it a legal designation established by the 1951 Convention Relating to the Status of Refugees. A refugee under the provisions of the Convention is defined as:

A person who owing to a well-founded fear of being persecuted for reasons of race, religion, nationality, membership of a particular social group or political opinion, is outside the country of his nationality and is unable or, owing to such fear, is unwilling to avail himself of the protection of that country; or who, not having a nationality and being outside the country of his former habitual residence as a result of such events, is unable or, owing to such fear, is unwilling to return to it (Convention relating to the Status of Refugees, 1951).

The Refugee Convention makes no mention of the environment as a possible inciting factor of displacement from an area of habitual residence, thereby excluding environmental migrants.

Secondly, the Refugee Convention is concerned with addressing circumstances of forced or involuntary migration; circumstances where a person could not reasonably choose to stay within their country of origin. The degree of volition involved in an individual instance of environmental migration generally occurs on a continuum where at one end of the continuum the migration is involuntary, e.g. displacement due to floods or earthquakes. On the other end of the continuum, the decision to migrate could come about completely voluntarily, e.g. migration from an agricultural region to urban area that improves livelihood. There have been several attempts to develop a classification that defines what constitutes voluntary environmental migration versus the involuntary variety (see Bates 2002 and Brooks 2010 for two examples); however, it has proven difficult to make clear distinctions between the two. Even in the event that it were possible to identify environmental migrants who have been displaced completely involuntarily, their status as refugees would still be impeded by the wording of the Refugee Convention, which requires that a person claiming to be a refugee experience a form of persecution. 
Finally, and perhaps most significantly, the majority of those displaced due to environmental causes do not cross an international border; rather, they are displaced internally and remain within the confines of their own country, and therefore would not be the focus of any policies or programs designed to assist convention refugees (Myers, 2002).

The issues noted above represent a significant challenge to advocates for environmental migrants who seek to include them under the current international refugee protection regime. Still more disheartening for environmental refugee advocates is the possibility that the environmental refugee concept is having a paradoxical effect, and refugee-receiving countries are seeking to limit their obligations under the Refugee Convention in order to avoid responsibility for an anticipated "flood" of environmental refugees (Black, 2001). It seems that conflating environmental migrants with political refugees is blurring the already well-established line of who has the legal right to seek asylum, thus potentially threatening the asylum process of convention refugees, instead of enlarging the refugee regime to include the environmentally displaced. In an effort to maintain the rights available to refugees under the current refugee protection regime, and develop a concept that is more encompassing of the multifaceted character of environmental migration, a number of alternative terms have been suggested, each with its own strengths and weaknesses.

Among the terms that appear in the environmental migration literature are "ecomigrant," which demonstrates the link between the economic and ecological factors that influence migration (Reuveny, 2008). "Environmentally displaced person (EDP)" is a useful term due to its similarity to "internally displaced person" (IDP); a displaced-persons category that has gained a degree of recognition through international soft law such as the Guiding Principles on Internal Displacement (Boano et al. 2008). Within contemporary writing, the term "environmental 
migrant" seems to have a significant level of support. The International Organization for Migration (IOM) has adopted the term and has put forward the following definition:

Environmental migrants are persons or groups of persons who, for compelling reasons of sudden or progressive change in the environment that adversely affects their lives or living conditions, are obliged to leave their habitual homes, or choose to do so, either temporarily or permanently, and who move either within their country or abroad (International Organization for Migration, 2007).

The IOM definition establishes that the environment can be a critical factor that influences an individual or group to migrate. The language used in the definition addresses acute, short-term displacement as well as chronic, long-term displacement, and takes into account the internally displaced in addition to those displaced across international borders. Further, the "environmental migrant" concept, as it is defined by the IOM, accounts for the multivariate nature of human displacement and allows for a range of environmental migration circumstances. It has been noted that the IOM definition is limited by its omission of language that distinguishes between voluntary and forced migration; nor does it identify which state or non-state institution is responsible for the persons displaced (Warner, 2010). However, it should also be noted that it would be difficult for any definition to completely account for the myriad of circumstances that constitute environmentally induced migration.

For example, the Refugee Convention required the addition of a subsequent Protocol in 1967 so that its protections could be extended to refugees outside of Europe. Moreover, the Convention made no reference to persecution based on sexual orientation; however, the right to claim asylum based on those grounds has been established through the development of jurisprudence relating to that issue, recognizing that an individual's sexual orientation would fall under the category of belonging to a 'social group' that faces persecution. The Refugee Convention has undergone a series of developments since its inception that allow it to function 
as the foundation of the international refugee regime as it exists today. Thus, the Convention's evolution demonstrates that the initial recognition of a category of displaced persons, however incomplete at the time, can serve as the basis for the development of policies and programs that can later be expanded upon to include constituencies that were initially excluded. Even without the recognition of international law, a generally agreed upon definition of environmental migration could be a starting point for furthering research and developing policies that effectively respond to incidences of environmentally induced displacement.

Researchers involved in the study of environmental migration argue that some form of international recognition of environmental migrants is an essential policy objective that must be met in order to gain wider support from the international community (see Brooks 2000; Boano et al. 2008; Myers 2002). Nevertheless, international recognition is only one aspect of a larger effort to address environmental displacement. The following section of this paper will examine the discussion surrounding formal recognition and review examples of state-level policy initiatives that have been put in place to manage environmental migration in the absence of formal international recognition. For the purposes of this paper, various terms may be used interchangeably to refer to environmental migrants; however, the definition provided by the IOM should serve as the point of reference for all subsequent discussion.

\section{ENVIRONMENT, MIGRATION, POLICY: MAKING THE CONNECTION}

As discussed, the causes of environmentally induced displacement are incredibly varied and interconnected; consequently, occurrences of displacement present policymakers with a set of challenges that span a wide array of policy areas. Policymakers tasked with addressing environmental migration have several considerations to be cognizant of, namely: that 
environmental migration decisions are usually based on a complex set of factors that often have as much to do with the attractiveness of the area of destination as with the risk associated with staying in an environmentally degraded area; the political, social, and economic environment in which potential migrants find themselves is often just as influential as the state of the natural environment; and that environmental migration policy must not only account for displacement once it occurs, but ideally should also seek to put in place measures that prevent environmental displacement from occurring in the first place. It should come as no surprise then that environmental displacement, a broad and difficult to define issue, gives rise to an equally broad set of policies found in areas as diverse as natural resource management, governance, international development, environmental protection, and national security (Boano et al. 2008; Brooks 2000). However, it is not the aim of this paper to review the range of policy options regarding the issue of environmental displacement; rather, the discussion will centre on migration policy, in particular its subcategories of immigration and refugee policy, as it relates to environmental displacement.

\section{International Recognition of Environmental Migrants}

Establishing some form of international recognition for environmental migrants is a policy objective that is prominent in current discussions concerning environmental migration. Certain advocates for environmental migrants have described international recognition in terms that portray it as the critical element of the wider effort to protect the environmentally displaced (see Biermann \& Boas, 2008; Brooks, 2000; Myers, 1993, 1998, 2002; Williams, 2008). Prominent international organizations such as the IOM and the United Nations University (UNU) have voiced their support for granting international recognition to environmental migrants. UNU- 
Environment and Human Security Director Janos Bogardi states, "there are well-founded fears that the number of people fleeing untenable environmental conditions may grow exponentially as the world experiences the effects of climate change and other phenomena... this new category of 'refugee' needs to find a place in international agreements. We need to better anticipate support requirements, similar to those of people fleeing other unviable situations" (UNU-EHS, 2005). Borgardi's statement falls short of calling for the sort of recognition granted to conventional refugees; however, it does underscore the international community's inability to find a place for environmental migrants within the existing protection framework for displaced persons. International recognition of environmental migrants can be viewed as a macro policy objective that is useful for its ability to support other policy initiatives. Often international aid is directed towards issues that have the backing of a constituency and its associated political leverage (Myers, 2002). Accordingly, international recognition of environmental migrants could be an important step towards developing an environmental migrant constituency that could direct resources and institutional support towards their particular needs.

Recognition, however, comes in various forms, each carrying with it a particular set of advantages and disadvantages. Effective forms of international recognition are legally binding and oblige states to acknowledge the rights, and adhere to the responsibilities, established by the legal agreement; such is the case for refugees as defined by the Refugee Convention. A binding form of legal recognition of environmental migrants is highly unlikely in the short-term since states are reluctant to take on additional protection obligations, especially obligations that impinge upon their national sovereignty (Williams, 2008). More likely is the establishment of "soft law," which provides a less formal degree of recognition, but establishes protocols that governments and international organizations can follow when managing cases of environmental 
displacement. Generally, soft law is used in conjunction with formal international law in order for states to cooperate on controversial issues such as international migration. The various resolutions, recommendations, declarations, and accords that fall under the category of soft law are especially effective when adapted to address regional migration issues particular to certain states (Opeskin, 2009). Betts (2008) argues that several states already participate in various agreements on human rights and the protection of vulnerable populations; therefore, the establishment of soft law would not necessitate the development of new norms and binding legislation. Rather, soft law could be structured to incorporate pre-existing human rights norms in established agreements in order to create guidelines that states can apply at their discretion. Betts (2008) contends that the principal elements necessary for the successful implementation of the kinds of soft law that would meet the needs of environmental migrants are "an authoritative consensus on the application" of the relevant guidelines combined with "a clear division of responsibility between international organizations [e.g. the UNHCR or the IOM] for the operational implementation of such guidelines"(p.5). In essence, Betts' argument is that soft law can be as effective as a binding agreement if there is commitment to the agreement from the states involved and competent support with the administration of the agreement from outside sources.

The Guiding Principles on Internal Displacement, established by the United Nations Office for the Coordination of Humanitarian Affairs is an example of soft law that could be expanded for application to environmental migrants or serve as a template for the creation of guidelines that apply to environmental migrants in particular. The IDP Guiding Principles, "which are based upon existing international humanitarian law and human rights instruments, are to serve as an international standard to guide governments as well as international humanitarian 
and development agencies in providing assistance and protection to IDPs" (UNOCHA, 2008).

IDPs as defined by the UNHCR in paragraph 2 of the Guiding Principles on Internal

\section{Displacement are}

Persons or groups of persons who have been forced or obliged to flee or to leave their homes or places of habitual residence, in particular as a result of or in order to avoid the effects of armed conflict, situations of generalized violence, violations of human rights or natural or human-made disasters, and who have not crossed an internationally recognized State border. (UNOCHA, 2008, p.1)

Note that the language concerning "violations of human rights or natural or human-made disasters" (UNOCHA, 2008, p.1) is of special relevance to environmentally displaced persons, and it would require minimal reinterpretation to apply the principles of protection to EDPs in addition to IDPs. Expansion of the Guiding Principles on Internal Displacement may offer an alternative to formal recognition, since over $90 \%$ of EDPs remain within the borders of their country of origin (Myers, 2002). However, that particular solution to environmental displacement could potentially leave millions of EDPs without recourse in the event that they do cross into another country. Furthermore, if the more alarmist predictions regarding the effects of climate change on future displacement prove to be correct there could be greater numbers of EDP's that seek the protection of neighbouring states. A case in point is the displacement occurring on the Polynesian island nation of Tuvalu. The 10,000 inhabitants of Tuvalu's lowlying islands are particularly at risk and face the possibility of becoming stateless if certain climate change predictions hold true and the entire island nation becomes submerged under the Pacific Ocean due to a rising sea-level (Lecky, 2009). In that event, the only recourse for the inhabitants of Tuvalu would be resettlement in a willing country; internal relocation for Tuvaluans would simply not feasible.

Expanding the IDP Guiding Principles to include environmental displacement would not 
meet the needs of all EDPs; nevertheless, soft laws such as guiding principles can be an effective mechanism for directing resources to certain constituencies while providing governments with the latitude necessary for them to adapt the principles in a manner that best meets their particular exigencies. Non-state actors such as non-governmental organizations (NGOs) and advocacy groups can use soft law as point of reference that lends support to their attempts to influence state-level migration policy. From a policymaking perspective, the guidelines and principles of soft law can serve as a framework upon which further policy developments are based. International law scholar Angela Williams (2008) observes, "IDP policies incorporate and build upon the international principles. This allows for states to be flexible in national implementation both in terms of timing and also regarding the extent to which substantive commitments are introduced, thereby allowing for domestic IDP policies to develop at their own pace and in response to localized concerns and events" (p.511). In the case of environmental displacement, a binding agreement could potentially impede a government's ability to implement polices that are developed for responding to a particular instance of environmental displacement, and instead require a predetermined course of action that may be ineffective in comparison to a specifically developed policy response. Diane Stone's (2004) examination of the "transnationalisation" of public policy is critical of the "one-size-fits-all" approach to policy implementation, noting that foreign experts often lack the contextual knowledge necessary to implement reforms. In many cases, an "informed adoption of 'best practice" can foster learning and be more effective than rigid adherence to a set of unfamiliar guidelines (p.11).

Though useful in certain contexts, the leeway that soft law offers to states may not necessarily lead to better policy. Soft law does not have the legislative significance of a binding agreement, and governments are under no obligation to follow its guidelines. States may choose 
to adhere to principles based on political expediency, watering down or ignoring principles that are controversial without prioritizing the needs of displaced persons. In contrast, binding agreements have the force of international law behind them, and place a greater onus on governments to meet the obligations set out by the agreement. The following discussion will move from the general concept of international recognition to more specific North American polices that address environmentally induced displacement.

\section{Living in Uncertainty: Temporary Protected Status in the United States}

At this time, there are no international agreements or guidelines regarding environmental displacement in place. In the absence of international recognition of environmental migrants, several countries have developed their own policies in response to environmental displacement. Two such polices, the Temporary Protected Status (TPS) provision used in United States, and the Canadian government's use of operational bulletins to issue special directives in response to displacement, are examples of the types of the environmental migration policies already in place at the state level. Like Canada, the United States is a signatory to the United Nations Refugee Convention. The Convention requires that signatory countries agree to the principle of nonrefoulement, which restricts states from returning foreign nationals to their country of origin if the life or freedom of the foreign national is threatened due to their "race, religion, nationality, membership in a particular social group, or political opinion (Convention relating to the Status of Refugees, 1951). The principle is central to refugee protection programs in both countries, but it has no provisions for foreign nationals, e.g. EDPs, who face life-threatening situations unrelated to persecution. In order to address the gap in protection "the United States Secretary of Homeland Security in consultation with the Secretary of State, can issue TPS for periods of 6 to 
18 months and can extend these periods if conditions do not change in the designated country" (Wasem et al. 2008, p.4). Unlike political asylum, which is granted on an individual basis according to the particular circumstance of the refugee claimant, TPS is a blanket protection available to all nationals, from any region of a designated country.

Following hurricane Mitch in 1998 and the Salvadoran earthquakes of 2001, deportations to El Salvador were suspended and Salvadoran nationals living in the United States were permitted to apply for TPS. Thousands of undocumented Salvadorans have since been granted TPS because of the measure, El Salvador's designation as a protected status country has been extended several times, and the measure remains in place today. Moutz, Wright, Miyares, and Bailey's (2002) offer a pointed critique of TPS and its effects in their study of Salvadoran immigrants in the United States. Their findings, based on a series of surveys and interviews, as well as participant-observation and participatory research involving community organizations and Salvadoran asylum claimants, revealed a great deal about migrants experiences of living with temporary status.

Moutz et al. describe the subjects of their research as "refugee-like, quasi-documented, non-citizen status prohibited El Salvadorans" (p.351) who live in constant uncertainty because of their tenuous legal status. Immigrants with TPS have the option to regularize their status with applications for asylum, although in practice, the process of regularization is characterized by long delays (several years in some cases) and significant uncertainty since only $25 \%$ of asylum claims from Salvadorans are successful in the US. Migrants with TPS interviewed in the study recount difficulties such as the inability to make basic decisions regarding household repairs, poor long-term job prospects, and indecision regarding whether to invite children or spouses to visit, even whether to buy furniture (p.348-51). Temporary and undocumented migrants are 
subject to exploitation by employers and may avoid accessing public services and legitimate immigration alternatives for fear of being deported if they make themselves known to authorities. Furthermore, migrants with TPS are required to maintain residence within the US, and are often unable to visit friends and family in their country of origin lest they risk losing what limited status they have. In effect, Mountz et al. portray immigrants under TPS as imprisoned by the very the system they sought protection from; existing in limbo, neither settled in the US nor free to return to their country of origin. The researchers go on to argue that economic considerations are at the centre of the TPS issue, since US businesses benefit from having a large, easily exploited, and inexpensive source of labour. Mountz et al. summarize their findings when they state, "Temporary Protected Status is neither protective nor temporary, and in fact damages immigrants, their families and the "host" society" (p.352). The results of Mountz et al.'s research are in line with other studies on temporary immigration status (see Bauder, 2002; Nakache, D. and Kinoshita, P. J. 2010; Wasem et al. 2008) that also demonstrate that low-skilled migrants with temporary status are particularly at risk of exploitation. Lacking the legal protections of conventional refugees, displaced migrants with temporary forms of status may find that they receive protection from one context of vulnerability only to find themselves confined to another.

\section{Special Measures: The Canadian Response to the 2010 Haitian Earthquake}

The population displacement that followed the 2010 Haitian earthquake epitomizes the multicausal nature of environmental displacement. The January 2010 earthquake, which struck near the Haitian capital city of Port Au Prince, causing widespread destruction and thousands of fatalities was a natural event made considerably worse by the human-made economic and political instabilities of Haiti's recent past. Poor construction standards, an underdeveloped 
infrastructure, and a general lack of public services turned an earthquake of major proportions into a tragedy of catastrophic scale. To illustrate this point, the 1989 San Francisco earthquake: (magnitude 7.0) was equal in strength to the 2010 Haitian earthquake, yet the San Francisco earthquake caused 63 casualties; a fraction of the tens of thousands of lives lost in Haiti (Brooks, 2010). Differences in natural risk factors may explain some of the disparity between the casualty statistics of the Haitian and San Francisco earthquakes; though it is difficult to ignore the role that Haiti's political, societal, and economic impoverishment played in exacerbating the environmental catastrophe of 2010. Myers (2001) notes that several decades of environmental and political mismanagement in Haiti has led to a situation where the majority of the Haitian population seeking asylum in other countries are doing so for environmentally related reasons, as opposed to the many who sought asylum from the persecution of authoritarian government during previous times in Haiti's turbulent history. In the aftermath of the earthquake, the Canadian government mounted a significant humanitarian response to the crisis. In addition to the financial and material resources provided by the Canadian government to assist with relief and reconstruction, Canadian migration policies played an important role in addressing the problems of environmentally induced displacement in Haiti.

On directions from its Minister, the Department of Citizenship and Immigration Canada (CIC) implemented several policies that facilitated the efforts of Haitian nationals seeking to enter or remain in Canada. The implementation of those policies was largely accomplished using operational bulletins, which CIC uses "in exceptional circumstances" to issue "one-time-only instructions or to provide urgent instructions to staff for a brief period" (CIC, 2011). Operational Bulletin (OB) 83 - Guidelines for Priority Processing in the Event of Disaster Situations, issued in 2008, and still in effect today, advises visa offices to use the discretionary powers granted to 
them by the Immigration Act to prioritize and expedite applications for permanent or temporary residence in Canada from countries affected by a natural disaster. OB 83 is a general operational directive. In effect, it is a reminder to visa offices that they possess the latitude necessary to respond to disaster situations in a "humane and expeditious manner" (CIC, 2009). CIC clearly states that $\mathrm{OB} 83$ is not a special program, nor priority processing, and it is the applicant's responsibility to demonstrate to the visa office that they or their family members have been adversely affected by the disaster.

Like the US's Temporary Protected Status, the Canadian government issues blanket Temporary Suspension of Removal (TSR) of nationals of designated countries affected by a disaster, in addition to making other temporary changes to immigration procedures. To provide instructions that are more detailed, operational bulletins that announce "special measures" are also be issued by CIC. Special immigration measures are put in place in order to implement programs and policies that deal with particular cases of displacement on an ad hoc basis. Unlike OB 83, special measures can involve the creation of new programs, provide visa offices with even greater latitude in decision-making, and offer blanket protections to entire categories of displaced persons. One such example is $\mathrm{OB} 179$ - Special Measures in Response to the Earthquake in Haiti.

Following the Haitian earthquake, OB 179 instructed CIC offices to deliver immigration services to Haitian nationals that they might otherwise be ineligible to receive. In order to expedite the immigration process for Haitians seeking permanent residence in Canada the special measures authorized the creation of the Ottawa Haiti Processing Office, which focused solely on processing immigration applications from Haiti. In addition, priority processing, fee exemptions, interim federal health coverage, as well as work and study permits were granted to selected 
Haitians seeking permanent residence. Further, a portion of the special measures addressed the ongoing adoption applications of Haitian orphans. The special program known as "Operation Stork," expedited the adoptions of Haitian orphans and evacuated several hundred Haitian children in the immediate aftermath of the earthquake (Taber, 2010).

The Canadian government's use of migration policy in the response to the disaster in Haiti was relatively significant in scale and provided protection to thousands of Haitian EDPs. Nevertheless, the temporary and ad hoc nature of the programs put in place should cause some concern amongst advocates for displaced persons. The special measures program has been criticized for delays in processing and its high refusal rate - as of February $2011,49 \%$ of all applicants to the special measures program were refused (Patterson, 2011). As discussed previously, gaps in protection and vulnerabilities may develop due to the implementation of temporary, ad hoc directives. Representatives from organizations that work directly with refugees in Canada identified TSRs as an area of concern to a Standing Committee on Citizenship and Immigration in 2006. Reinforcing Mountz et al.'s findings, the committee participants noted, "although protected from immediate removal, they [displaced persons] are unable to become permanent residents and go on with their lives; they are forced to work in lowpaying jobs; and they have limited access to health services and education." (CIC, 2006).

Special measures and TPS provide governments with the ability to offer a measure of protection to foreign nationals affected by environmentally induced displacement. The ad hoc nature and temporary duration of these policy instruments are appealing to governments since special measures and TPS are adaptable policies that allow a government to prioritize humanitarian crises while keeping in mind other economic, security, and political considerations without being bound to a certain course of action by international law. However, those same 
characteristics have the potential to undermine the already precarious security of environmentally displaced persons. Governments may use their discretion to select which disasters they respond to based on the character or match of the country. For example, there was significant public debate regarding the discrepancy between Canada's vigorous humanitarian response following the Haitian disaster, and the relatively subdued response to large-scale flooding in Pakistan just a few months later (Blanchfield, 2010). Further, temporary policy directives generally leave no recourse for judicial review or appeals of decisions, and do little to address the long-term requirements of environmental migrants in the host country or the precipitating problems in the country of origin. Environmental migrants with temporary forms of status may benefit from a respite from deportations to a country ravaged by natural disaster. However, unless further measures to regularize the status of environmental migrants are put in place they may be found in a situation where they are forced to choose between remaining in a country of asylum with irregular immigration status or returning to what is perhaps a still dangerous country once the temporary directive expires.

Lacking international recognition, displaced persons as a constituency, are at a disadvantage in terms of their ability to affect the development of migration policy. Although, within the existing legislative and political context there are opportunities for advocates of environmentally displaced persons to exert influence on the processes by which temporary directives - and migration policy more broadly - are formulated. The use of migration policy as a method of addressing environmentally induced displaced is a recent development in the context of Canadian immigration policy. Nevertheless, the history of migration policy in Canada provides several examples of advocates for displaced persons, as well as other interest groups, both domestic and international, influencing the development of policy in favour of displaced 
persons. With significant levels of per capita immigration and refugee resettlement, in addition to a history as a settler-society, Canada's migration policy is especially relevant to a discussion of environmental migration policy. Thus, the following discussion will focus on trends in Canadian immigration and refugee policy as it relates to displaced persons, and will discuss the role of domestic and international political influences in the development of said policy.

\section{REFUGEE POLICY IN CANADA}

Throughout Canada's history, the country's immigration policy has prioritized international migration that best contributes to Canada's economic growth. Be it settling the sparsely populated Canadian West for the purpose of agriculture, or the current focus on high-skilled immigrants and temporary foreign workers, Canada's tendency to relax admission requirements and allow large influxes of migrants usually occurs in conjunction with some form of economic imperative. Despite the overarching economic motivations associated with Canadian migration policy, immigration based on humanitarian factors has also played a significant role in the development of Canada's immigration system as it exists today.

Immigration policy in Canada has experienced periods of relative openness towards individuals seeking protection, in addition to periods during which harsh restrictions are placed on asylum seekers. From the acceptance of British Loyalists following the American Revolutionary War to the reception of 60,000 refugees fleeing war torn Vietnam during the early 1980's, Canada has demonstrated a willingness to adjust its policies to take humanitarian factors into greater consideration (Kelly and Treblicock, 1998). However, Canadian immigration policy has taken positions that are altogether at odds with its current priorities to "offer protection to those in need... and come to the aid of displaced individuals" (CIC, 2010). A poignant example 
of Canada's more restrictive stance on humanitarian migration was the federal government's unwillingness to accept Jews fleeing Nazi persecution during the Second World War. Motivated by the widespread anti-Semitic sentiment that existed at the time, the Canadian position regarding Jewish refugees during World War II was vividly demonstrated by the country's refusal to admit the over 900 Jewish asylum seekers aboard the MS St Louis ocean liner. The Jewish refugees who arrived off the coast of Halifax, Nova Scotia in 1939 eventually returned to Europe, where many lost their lives in the ongoing conflict (Knowles, 2007, p.143-45).

Canada's polices concerning refugee admissions were generally developed and implemented ad hoc until the country formally committed to the Refugee Convention in 1969. This step began the transition towards a formal process of granting protection to asylum seekers. However, at this time, there still exist large classes of displaced persons who are not covered under the formal refugee process. Furthermore, with the stated reason being the effort to reduce the number of fraudulent asylum claims, the Canadian government is taking steps to restrict the flow of refugees under certain categories even further. For example, a provision of the recently passed Bill C-11, the Balanced Refugee Reform Act, places a limit on the availability of a risk assessment before removal from Canada. A Pre-Removal Risk Assessment (PRRA) determines if it is safe to return a foreign national to their country of origin and under the new law failed asylum claimants would not have access to the assessment for a period of one year from the date of the negative decision regarding their refugee claim (CIC, 2011).

The following discussion provides some background on the history of humanitarian migration to Canada, while paying attention to key moments in which Canada has adjusted its refugee policy in the face of domestic and international pressures. Past refugee influxes as well as contemporary responses to displacement are discussed in order to better understand how 
Canada responds to crises that cause population displacement. A review of selected cases will demonstrate the principal actors involved in influencing the development of Canada's migration policy response to humanitarian crises that lead to displacement. The history of Canadian refugee policy contains lessons pertinent to a discussion of environmental displacement. The influence of public interests, e.g. NGOs and community organizations, in determining the degree of government response to humanitarian crises is particularly relevant to current efforts to advocate policies that effectively respond to the needs of the environmentally displaced.

\section{Canadian Refugee Policy: Background Information}

The majority of individuals admitted to Canada based on humanitarian grounds today would not have been allowed to do so less than a century ago. For much of its history Canada placed significant restrictions on immigration from all but a few northern-European countries, and further restrictions were placed upon anyone whom the government thought was at risk for becoming a public charge (Kelly and Treblicock, 1998). It was not until the end of the Second World War that Canada relaxed its immigration rules to al̄ow large-scale humanitarian migration by Europeans affected by the displacement caused by the conflict. Canada admitted over 430,000 immigrants between 1946 and 1950, with the trend of increased humanitarian admissions continuing until 1957 when total immigration peaked at 282,000 admissions for that year alone (Knowles, 2007). Although the figures fluctuate, Canada currently admits 25,000 refugees per year (Statistics Canada, 2009). Figure 2 below illustrates recent trends in refugee admissions to Canada. 


\section{FIGURE 2}

Canadian Refugee Admissions 1981-2009

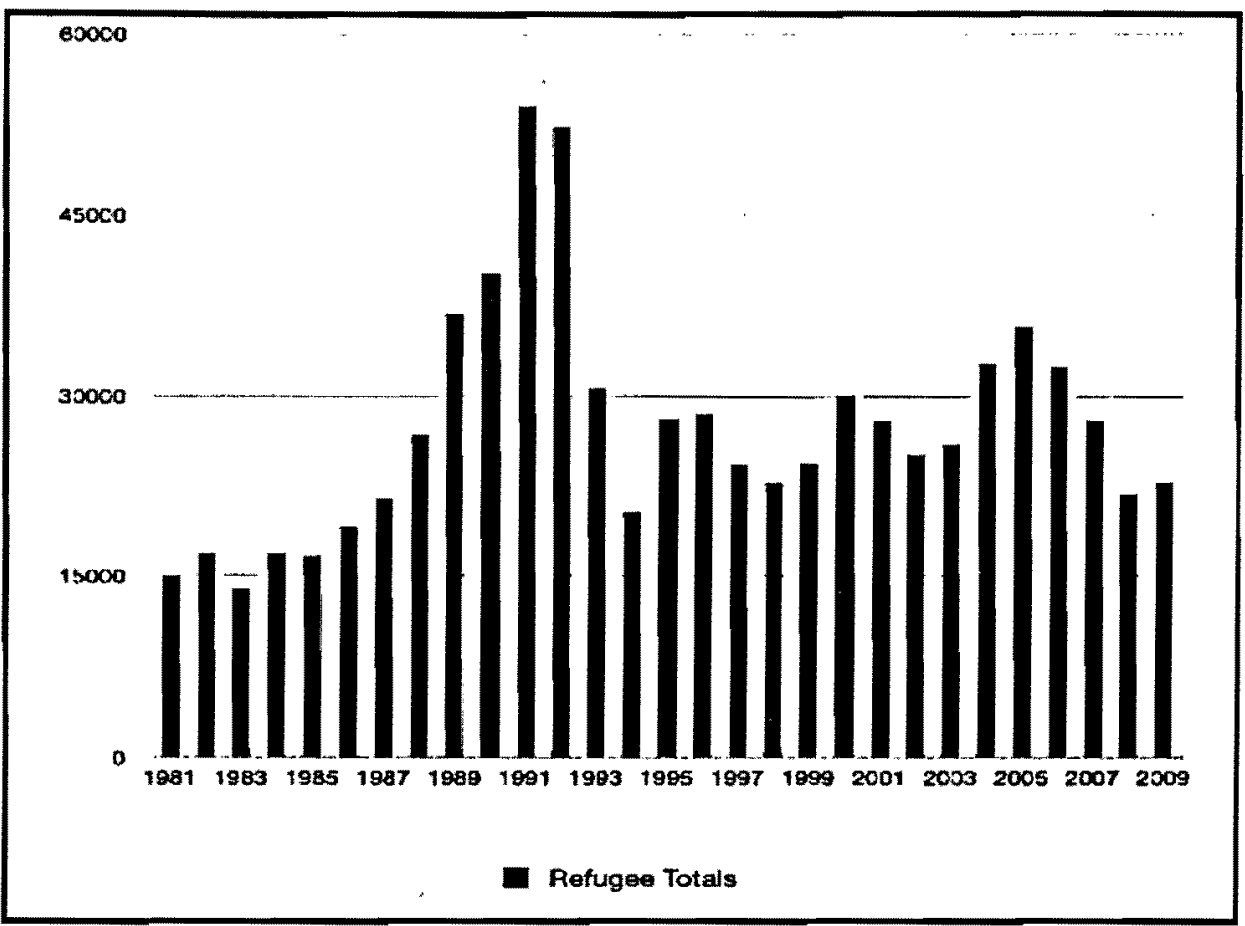

Source: Citizenship and Immigration Canada (2009) Canada Facts and Figures: Immigrant Overview - Permanent and Temporary Residents

Refugees displaced due to the political and economic turmoil in Europe following World War II comprised the majority those admitted to Canada during the post-war period. A significant number of migrant admissions to Canada during the post-war period originated from the United Kingdom, with many others originating from European countries such as Germany, the Netherlands, Italy, Poland, and the U.S.S.R. (Boyd and Vickers, 2000). Despite Canada's increased admissions of immigrants on humanitarian grounds following the Second World War, the government's immigration policy still contained many provisions that placed serious constraints on the ability to request asylum. Canada routinely excluded large numbers of asylum seekers based on criteria that would be viewed as discriminatory under current law. John Holmes, an External Affairs officer and a critic of Canadian refugee policy during that period 
stated that Canada selected its refugees "like good beef cattle..." (Kelley and Treblicock, 1998, p.339).

The new, post-war, humanitarian admissions to Canada were permitted through Orders in Council, as well as other provisional measures that did not provide significant legal guarantees to asylum seekers. Following a recommendation from the Royal Canadian Mounted Police (RCMP), Canada refused to commit to the 1951 Refugee Convention, claiming that it would interfere with its ability to deport non-citizens. It was not until 1967 that Canada ratified the Refugee Convention, and committed to the resettlement of refugees as defined by the Convention. Canada's ratification of the Refugee Convention was a significant step, and subsequent to the ratification Canada began to grant refugees from outside of Europe the opportunity to request the protection offered by permanent residence. By 1978 , a new Immigration Act that legislated the administrative measures put in place in 1967 came into effect and included provisions for admission to Canada based on humanitarian factors. The Act formalized many aspects of Canada's asylum process by making a clear distinction between immigrants and refugees, and establishing a program that allowed Canadians to privately sponsor refugees.

An independent administrative tribunal, known today as the Immigration and Refugee Board, was established and given responsibility for making refugee determinations. Canada's policies regarding humanitarian migration continued to develop in the following decades, and the country came to be globally recognized as an important contributor to the cause of refugee resettlement. In 1986, the Nansen Refugee Award, awarded "in recognition of extraordinary and dedicated service to refugees... the most prestigious honour conferred by United Nations High Commissioner for Refugees (UNHCR)" was awarded to the Canadian people (UNHCR, 2011). It 
remains the only time that a country as a whole has received that honour. However, the pendulum of Canada's humanitarian migration policies has begun to swing, once again, towards restrictive regulations that have tended to favour greater securitization of migration, and harmonization of policies with other countries of immigration. The 2004, Safe Third Country Agreement between Canada and the United States, which effectively denies refugees the possibility of making an asylum claim to Canada at the Canada-US border is a recent example of the Canadian government's attempt to restrict the flow of migrants who enter Canada based on humanitarian factors. The recently passed Balanced Refugee Reform Act, which has among its aims, the goal of limiting the number of refugee claims by shortening the decision process is another example of the shift away from humanitarian migration.

Recent changes to Canada's policies regarding humanitarian migration should be a point of interest amongst advocates of environmental migration issues since shifts in Canada's humanitarian migration policy are not arbitrary; rather, the changes reflect the various domestic and international forces that exert pressure on a government's decisions. Parallels can be drawn between Canada's previous decisions concerning cases of displacement and the likely response of developed countries to future incidences of environmentally induced migration. To better contextualize the discussion regarding migration policy decisions at the state-level an examination of specific cases of displacement that have lead to shifts in Canada's humanitarian migration policies will follow.

\section{Canadian Refugee Policy: Historical Precedents}

An examination of incidences of displacement and the subsequent policy response of the Canadian government is germane to a discussion of environmental migration policy because it 
establishes a context within which questions relating why national governments intervene in certain incidences of displacement and not others can be explored. The Hungarian, Indochinese, and Chilean refugee crises were large-scale refugee movements that involved several domestic and international interests in the formation of Canada's policy response. Thus, the cases are ideal for an exploration of the vicissitudes that are at times inherent in the development of humanitarian migration policy.

\section{The Hungarian Refugee Crisis of 1956}

Following the end of the Second World War, the Canadian government placed significant restrictions on the admission of refugees that did not meet the racial and geographic criteria for admission that it required of all immigrants. The stringent criteria had the effect of limiting the overall number of immigrants, the majority of whom were from the United Kingdom (Kelley and Treblicock, 1998). However, following the 1956 Soviet invasion of Hungary, Canada admitted over 37,000 Hungarians due to humanitarian factors. The admission of the Hungarian refugees was a departure from Canada's long held position regarding the inadmissibility of immigrants from countries outside of Northern Europe.

The policy shift was the result of a combination of factors. The post-World War II period was one in which international cooperation was strengthened in several spheres in an effort to rebuild Europe. By the mid-1950s Australia, France, Germany, Ireland, Italy, The Netherlands, Norway, Sweden, and Switzerland, amongst other countries had ratified the UN Convention relating to the Status of Refugees (Loescher, 2008). Those, and several other western countries began to accept some of the more than 200,000 Hungarians who had fled their country; consequently, giving Canada additional incentive to welcome the refugees as well (Kelley and 
Treblicock, 1998). After a formal request for aid from the Austrian government, the UNHCR, which obtained new powers to operate in displacement situations, made direct requests to third countries for resettlement solutions (Loescher, 2008). Canada was among the counties petitioned by the UNHCR for resettlement assistance, and in addition to international pressure from foreign countries and inter-governmental organizations, significant domestic pressures existed as well. Initially, the Minister of Citizenship and Immigration Jack Pickersgill, stated that the Hungarians would be given priority in immigration processing, but there would be no further change in policy. However, urging from various public interest groups within Canadian society pressured the Minister to make concessions. Religious organizations such as Jewish Immigrant Aid Services, the Canadian Council of Churches, and the Catholic Immigration Aid Society, which had successfully lobbied for admissions based on humanitarian grounds at previous times, placed significant pressure on the Liberal government of Louis Stephen Saint-Laurent. Opposition parties, the Conservatives and the CCF, joined ethnic groups in denouncing the Minister's decision. The business community, interested in adding to the pool of skilled labour, was particularly enthusiastic about absorbing Hungarians who had training in engineering and forestry. In addition, the nation's newspapers were also critical of the government's restrictive stance. The Globe and Mail, an influential Canadian daily newspaper, wrote an editorial criticizing the government's policy with a headline that read "For Shame." Faced with mounting public pressure, the government reversed its position and Pickersgill announced that the government's position had always been to "accept these people as long as they want to come here and it looks as though we can find accommodation for them..." (Kelley and Treblicock, 1998, p.340). Transportation loans were issued, plans to house and feed the refugees were developed, and the Minister made the exceptional decision to fly to Vienna to personally oversee 
the transfer of the Hungarian refugees (Kelley and Treblicock, 1998). Knowles (2007) describes the Canadian response to the Hungarian refugees as "one brief period of glory in the... handling of immigration and one of the few times in Canadian history when Canadians have wholeheartedly welcomed immigrants" (p.173).

\section{A Decade of Tumult: Refugee Crises during the 1970's - Chilean "Communists" \& Indochinese "Boat People"}

The levels of displacement that occurred during the post-World War II period showed no signs of abating during the1970's; a decade of political turmoil in which violent government-backed oppression and military coup d'états in Argentina, Chile, Greece, the Soviet Union, Uganda, Uruguay and Vietnam resulted in large refugee movements (Loescher, 2008). Two such events, the mass exodus of tens of thousands from Chile after a coup d'état in 1973, and the Indochinese refugee crisis of 1975 , present two very different illustrations of the Canadian government's willingness to put in place migration policies that respond to needs of displaced persons.

The ouster of the democratically elected socialist President of Chile, Salvador Allende, by a right-wing military junta lead by Augusto Pinochet resulted in a mass refugee movement of Chileans fleeing the violent political oppression of the Pinochet regime. Immediately following the coup, the Pinochet regime moved to consolidate its hold on power, imprisoning, torturing, and killing, thousands of former Allende supporters and left-wing sympathizers. Chileans fleeing the violence moved en masse into neighbouring countries creating a large-scale refugee crisis requiring resettlement solutions (Kelly and Treblicock, 1998; Loescher, 2008; UNHCR, 1996). Just a few years after the Chilean crisis, events following the end of Vietnam War lead to the displacement 3 million people from Vietnam, Laos, and Cambodia. Most of the Southeast Asian refugees fled to Thailand and Malaysia. Many of the Vietnamese refugees braved dangerous 
waters and pirates in dilapidated boats in order to flee the country, thus receiving the label of "boat people." The scale of the displacement quickly overwhelmed the ability of neighbouring countries to respond to the crisis, leading to Vietnamese "boat people" being turned away at the shores. In order to address the worsening crisis, the International Conference on Indochinese Refugees was held in July 1979 , resulting in agreements to resettle Vietnamese refugees in several Western countries, including Canada (Loescher, 2008).

The commonalties in the experiences of displacement shared by the Indochinese and the Chileans did not engender a matching policy response from the Canadian government.

In a partial replay of history, many of the same factors that figured in the Hungarian refugee movement resurfaced in the Indochinese immigration saga. These included: mounting international pressure for countries in the West to admit refugees for resettlement, an upsurge in Canadian media coverage of the refugee question; a corresponding increase in public interest in the issue; and a demand by Canadian churches and voluntary agencies that government pursue a more aggressive refugee policy. (Knowles, 2007, p.216)

By the early 1970's the racial and geographic restrictions on refugee resettlement to Canada had been lifted; the Canadian economy (frequently a bellwether of the Canadian attitude towards refugee resettlement) was strong; and there was a high level of public interest in both crises; factors that portended well for a strong humanitarian response from the Canadian government (Kelly and Treblicock, 1998). Furthermore, responding to the displacement of the Indochinese was a priority for the United States, which maintained a geopolitical interest in the region that stemmed from the Vietnam war, as well as the US's wider goals of blunting the influence of communism in the region. Thus, Canada, the US, and several other Western nations responded by putting in place special immigration measures and initiating a large-scale resettlement effort. Although slow to respond at first, Canada ultimately admitted 60,000 Vietnamese refugees by 1980. The Canadian response to the displaced Vietnamese represented the largest refugee intake 
to Canada since the Hungarian crisis that took place almost a generation earlier (Kelly and Treblicock, 1998).

The welcoming response to Vietnamese refugees contrasts sharply with "grudging" acceptance of Chilean refugees during the same period (Knowles, 2007, p.215). Public support for the Chilean refugees was high, and a coalition of interests that included the UNHCR, the Canadian Council of Churches, labour, and Latino groups attempted to lobby the Canadian government. Despite the efforts of advocates for the Chilean refugees, the Canadian government was reluctant to provide asylum to refugees that they viewed as having a left-wing ideology. Unlike their Vietnamese counterparts, the Chilean refugees fell on the wrong side of the ideological divide, and from the perspective of the Canadian government, the Chileans represented a threat (Kelly and Treblicock, 1998). Members of Parliament (MPs) from the opposing New Democratic Party of Canada were critical of the governing Liberal government's stance, yet they were alone among Canada's major political parties in offering their support to the Chileans. During debate on the Chilean crisis, Social Credit MP Réal Caouette asked, "Is the department considering the advisability of suggesting to Chilean immigrants to go rather to the USSR, Cuba, the People's Republic of China and Algeria where ideologies would more in keeping with their deep convictions and yearnings?" (Knowles, 2007, p.366). Canada's intransigence towards Chileans seeking asylum culminated in migration policy that subjected the refugees to an exhaustive security screening and long-delays in processing. 6700 Chilean refugees were eventually accepted, however, observers noted that Canada's response to the Chilean crisis was among the worst of any Western country (Kelly and Treblicock, 1998), Special measures similar to the ones issued to deal with the displacement crises that occurred post-World War II and during the 1970's are still an important piece of Canada's 
overall migration policy. Special measures programs were implemented for refugee crises in Lebanon 1979, Poland 1980, El Salvador 1981, Sri Lanka 1983, China 1989, Kosovo 2000, and Haiti beginning in 2010. Moreover, a similar confluence of international and domestic influences continues to play an important role in determining which refugee crises receive attention. However, it should be noted that not every major incidence of displacement elicits a Canadian response. Kelly and Treblicock (2008) highlight two notable exceptions: Afghanistan and Africa. Although civil war and ethic conflict have ravaged both regions, which are frequently sources of large refugee movements, Canada has not put in place significant migration polices to aid in the repeated refugee crises affecting the regions. The Canadian government has repeatedly maintained that the solution to Africa's problems "can only be found in Africa, by Africans" (Kelly and Treblicock, 1998, p.411). Perhaps, in a manner similar to the Chilean refugee crisis, ideological differences, foreign government influence, or some other form of bias may explain Canada's unwillingness to accept refugee from Afghanistan and Africa. At the time of this writing, the worst drought in 60 years, widespread famine, and persistent conflict have displaced hundreds of thousands of Somalis (UNHCR, 2011). Canada has contributed millions of dollars in humanitarian aid, yet the Canadian government has not included migration policies such as TSR or special immigration measures as part of its humanitarian response to the crisis. Canada's policy regarding African refugees corresponds with several other Western countries, which generally advocate using third-country resettlement only as a last resort when responding to crises in Africa.

The absences and inclusions of certain refugee populations in Canada's humanitarian migration policy highlight the role of advocacy in shaping polices for displaced persons, and demonstrates the range of actors that may be involved in influencing a government decision 
related to humanitarian migration. External factors such as decisions by foreign governments and international organizations often play a significant role in influencing domestic migration policy. Furthermore, domestic public interests such as ethnic, political, and business groups demonstrate the ability to successfully lobby the government and sway public opinion in order to bring about changes in policy.

\section{DISCUSSION}

Returning to the primary focus of this paper, the question that remains to be answered is: what does the study of Canadian refugee policy contribute to an understanding of the links between migration policy and environmentally induced displacement? It is difficult to generalize based on a small sampling of cases. Nonetheless, the preceding discussion reveals useful insights relevant to issues of environmental displacement.

Firstly, migration policy is demonstrably an important part of humanitarian responses to environmental displacement. The causes and consequences of displacement are complex, requiring input from a wide range of policy areas; nevertheless, it seems clear that Canada, and by extension other Western nations, believe that migration policy has a seat at the table in debates regarding the appropriate response to displacement - environmentally related or otherwise. Be it the Vietnamese fleeing the violent oppression of a dictatorial government or Haitians seeking to rebuild their lives after an earthquake, facilitating the efforts of people trying to escape dangerous circumstances ought to be a key part of the policy discussion.

Secondly, migration policy is anything but static, and government decision-making does not occur in isolation. Every government will have its own agenda and priorities regarding humanitarian responses; they are, nonetheless, subject to a complex interplay of interests, both 
domestic and international. For example, despite Canada's significant level of involvement in the response to Haiti's EDPs in 2010, the relief efforts required the contributions of various international organizations and foreign governments, each with their own particular set of objectives, in addition to the resolve of the Haitian people themselves. Environmental migration is characterised by its interrelations with a range of other social, political, security, and economic issues. The complexity and scale environmental migration events require that an effective response have the widespread support of the international community. In the Canadian context, internationally, foreign governments (particularly the United States) and inter-governmental organizations (particularly the UNHCR) are influential in determining the direction of Canada's migration policy. Thus, the current level of support for environmental migrants is not solely dependent on the policy direction of any individual nation. Major changes to current polices regarding environmental displacement would require the support of a significant contingent within the international community.

Domestically, wide arrays of public interests are able to influence a government's course of action on displacement issues. The media, ethnic groups, the business community, and NGOs, are a sampling of the many domestic interests that have shaped the development of Canadian migration policy. By no means are all interests equally represented in debates over migration policy. Displaced persons and their advocates require significant levels of public support to be effective, and even with such support, there are no guarantees that government will respond favourably. During the 1970's, UNHCR recommendations, lobbying by ethnic and religious organizations, as well as other forms of domestic and international pressure tipped the balance in the favour of Vietnamese refugees, while those same forces were ineffective at obtaining similar support for Chilean refugees. Generally, public interests are not the sole determinant of a 
government's migration policy direction; however, it has been demonstrated that public pressure, effectively applied, can at times influence the humanitarian response of a national government regarding displaced persons.

Finally, and perhaps most importantly, Canadian migration policy offers interesting lessons regarding the future direction of environmental migration policy. In the short-term, it is likely that governments will continue to respond to incidences of environmental displacement using reactive, ad hoc, and usually temporary measures. The history of refugee policy in Canada demonstrates that special measures and ad hoc responses are the norm, while the formal protections offered to refugees as defined by the Convention are an exception to this standard practice. The international refugee regime was borne out of the particular circumstances of displacement that arose during the aftermath of the Second World War. Environmental displacement has yet to have an analogous impact on Western nations and without a comparable level of disruption, it is unlikely that a response of a similar magnitude will occur.

\section{CONCLUSION}

Environmental migration is far from a settled issue. There have been significant advances in the field of study, however a lack of consensus remains, and more research is needed to better assess the scale of environmental displacement and accurately predict future trends in global population movements as a result. Regardless of the research consensus, the current "wait and see" approach of most Western governments is likely to remain in place for the foreseeable future, as governments are increasingly unwilling to expand upon international obligations to protect displaced persons. As discussed, there are advantages to the current "wait and see" approach; essentially, the current approach provides autonomy and latitude to states devising a policy 
response to a given crisis. The disadvantages, however, lay in the lack of a stable, long-term approach to responding to environmental displacement.

Whether through soft law or another legal or policy mechanism, some form of international recognition of environmental displacement is a prerequisite for organizing resources to meet the particular needs of EDPs. From Nepal to El Salvador, the cases discussed in this paper demonstrate that the causes and consequences of environmental migration cannot be separated from the wider social, political, and economic context within which the displacement occurs. Addressing climate change, reducing global poverty, promoting stable and responsive governance in affected countries are examples of the kinds of long-term initiatives that are imperative to meeting the needs of environmentally displaced persons at the international level. Domestically, focusing on the long-term resettlement of displaced persons and addressing the problems caused by temporary forms of protected status are challenges that should be addressed as well. These long-term initiatives are an alternative to the "wait and see" approach, and in some cases they may be more effective at managing crises in regions that demonstrate a pattern of displacement and environmental deterioration. The absence of certainty on the issue of environmental migration ought not serve as an excuse for inaction on the needs of the displaced as there are current and pressing crises in many parts of the world that require bold policy and urgent attention. The task is made difficult by the fact that in many ways the field of environmental migration is in uncharted territory. Never have so many people, so drastically altered the environment and made so severe a demand on the Earth's finite resources. The exact effects of climate change and uncontrolled development are difficult to predict; however, we may find that regardless of our desired policy response, the reaction of the natural environment to our continued pressures may have the final say on future global migration patterns. 


\section{REFERENCES}

Annan, K. (1999). Address on the closing of the international decade for natural disaster reduction. Paper presented at the International Decade for Natural Disaster Reduction Geneva, Switzerland. Retrieved from http://www.unisdr.org/unisdr/forum/proceedannan.htm.

Associated Press, (2010, September 24). Nigeria flooding displaces 2 million CBC News Retrieved from http://www.cbc.ca/news/world/story/2010/09/24/nigeria-floods-dams.html Bauder, H. (2007). What a difference citizenship makes! Migrant workers in rural Ontario. Our Diverse Cities, (4), 95-98.

Bates, D. C. (2002). Environmental refugees? Classifying human migrations caused by environmental change. Population and Environment, 23(5), 465-477.

Betts, A. (2008). Towards a "soft law" framework for the protection of vulnerable migrants (Research Paper No. 162). Geneva, Switzerland: UNHCR - Policy Development and Evaluation Service.

Black, R. (2001). Environmental refugees: Myth or reality?" (UNHCR Working Paper No. 34). Geneva: UNHCR.

Blanchfield, M. (2010, September 14). Canada boost aid to Pakistan, still well short of Haiti response. The Toronto Star, Retrieved from http://www.thestar.com/news/world/pakistan/article/860789--canada-boosts-aid-to-pakistanstill-well-short-of-haiti-response

Boano, C., Zetter, R. \& Morris, T. (2008). Environmentally displaced people (Policy Briefing). Oxford, UK: Refugee Studies Centre - Oxford Department of International Development. 
Bojaowski, A. (2011, April 18). UN embarrassed by forecast on climate refugees. Spiegel

Online, Retrieved from http://www.spiegel.de/international/world/0,1518.757713,00.html

Boyd, M. and Vickers, M. (2000) 100 Years of immigration in Canada. Canadian Social

Trends,No.58, Fall, 200. 2-12. http://dsp-psd.tpsgc.gc.ca/Collection-R/Statcan/11-008-

XIE/0020011-008-XIE.pdf

Brooks, D. (2010, January 15). The underlying tragedy. The New York Times, p.A27.

Brooks, S. (2000). Environmentally induced migration: Beyond a culture of reaction.

Georgetown International Environmental Law Review, 14, 855.

Brown, 0 . (2007) Climate change and forced migration: Observations, projections and implications (Background paper No. 17). Geneva, Switzerland: United Nations

Development Program. Retrieved from http://hdr.undp.org/en/reports/global/hrd-20072008/papers/brown_oli.pdf

Castles, S. (2002). Environmental change and forced migration: Making sense of the debate (UNHCR Working Paper No. 70). Geneva: UNHCR.

Citizenship and Immigration Canada. (2006). Policies and regulations - fact sheets on refugee issues. Retrieved 06/14, 2011, from http://www.cic.gc.ca/english/department/lawspolicy/responses.asp\#\#part5

Citizenship and Immigration Canada. (2009). Operational bulletins 083: Guidelines for priority processing in the event of disaster situations. Retrieved 07/23, 2011, from http://www.cic.gc.ca/english/resources/manuals/bulletins/2008/ob083.asp

Citizenship and Immigration Canada (2009) Canada Facts and Figures: Immigrant Overview Permanent and Temporary Residents. Retrieved 07/ from http://www.cic.gc.ca/english/resources/statistics/facts2009/index.asp 
Citizenship and Immigration Canada. (2010). Operation stork: February 23, 2010 update.

Retrieved 01/19, 2011, from

http://www.cic.gc.ca.ezproxy.lib.ryerson.ca/english/department/media/notices/notice-

haiti31.asp

Citizenship and Immigration Canada. (2010) 2010-2011: Reports on plans and priorities

Retrieved 08/09, 2011, from

http://www.tbs-sct.gc.ca.ezproxy.lib.ryerson.ca/rpp/2010-2011/inst/imc/imc-eng.pd

Citizenship and Immigration Canada. (2011). Operational Bulletins 2011 Retrieved 01/19, 2011,

from http://www.cic.gc.ca/english/resources/manuals/bulletins/2011/index.asp

Citizenship and Immigration Canada. (2011). Balanced refugee reform Retrieved 06/15, 2011,

from http://www.cic.gc.ca/english/refugees/reform.asp

El-Hinnawi, E. (1985). Environmental Refugees. Nairobi, Kenya: United Nations

Environmental Programme.

Gemenne, F., \& Dun, O. (2008). Defining 'environmental migration'. Forced Migration Review, (31), 10-11.

Gillis, J. (2010, November 14). As glaciers melt, science seeks data on rising seas. The New York Times, pp. A1.

Intergovernmental Panel on Climate Change (IPCC). (1990) Climate Change: The IPCC Scientific Assessment: Final Report of Working Group I. Cambridge University Press, New York.

International Organization for Migration. (2007). Migration and the environment. Paper presented at the 94th Council Session, Geneva, Switzerland. 1. 
Kibreab, G. (1997). Environmental causes and impact of refugee movements: a critique of the current debate, Disasters, Vol. 21(1), p. 20-38.

Kelley, N., \& Treblicock, M. J. (1998). The making of the mosaic: A history of Canadian immigration policy. Toronto: University of Toronto Press.

Knowles, V. (2007). Strangers at our gates (Revised Edition ed.). Toronto: Dundurn Press. Loescher, G. (2008). In Betts A., Milner J. (Eds.), The united nations high commissioner for refugees (UNHCR): The politics and practice of refugee protection into the twenty-first century. New York: Routledge.

Leckie, S. (2009). Climate-related disasters and displacement: Homes for lost homes, lands for lost lands. In J. M. Guzmán, G. Martine, G. McGranahan, D. Schensul \& C. Tacoli (Eds.), Population dynamics and climate change (1st ed., pp.119-132) United Nations Population Fund (UNFPA).

Laczko, F. (2010). Migration, environment, and climate change: Assessing the evidence. Paper presented at the First Workshop on Climate-Induced Migration and Displacement in MENA, Marseille, and France.

Massey, D., Axinn, W., \& Ghimire, D. (2010). Environmental change and out-migration: Evidence from Nepal. Population and Environment, 32(2-3), 109-136.

McGranahan, G., Balk, D., \& Anderson, B. (2007). The rising tide: Assessing the risks of climate change and human settlements in low elevation coastal zones. Environment \& Urbanization, 19(1), 17-37.

Mountz, A., Wright, R., Miyares, I., \& Bailey, A. J. (2002). Lives in limbo: Temporary protected status and immigrant identities. Global Networks, 2(4), 335-356. 
Myers, N. (1993). Environmental refugees in a globally warmed world. BioScience, 43(11), 752761.

Myers, N. (1997). Environmental refugees. Population and Environment, 19(2), 167.

Myers, N. (2002). Environmental refugees: A growing phenomenon of the 21st century.

Philosophical Transactions of the Royal Society of London. Series B: Biological Sciences, $357(1420), 609-613$.

Nakache, D. and Kinoshita, P. J. (2010). The Canadian temporary foreign worker program: Do short-term economic needs prevail over human rights concerns? IRPP Study No. 5.

Office of the United Nations High Commissioner for Refugees (1951). Convention Relating to the Status of Refugees. Retrieved 05/14, 2011 from http://www.unhcr.org/3b66c2aa10.html

Opeskin, B. (2009). The influence of international law on the international movement of persons. (Human Development Report No. 18) United Nations Development Programme. Retrieved from http://hdr.undp.org/en/reports/global/hdr2009/papers/HDRP_2009_18.pdf

Patterson, K. (2011, February 10). Immigration "fast track" not so fast. Ottawa Citizen, pp. A3. Stone, D. (2004). Transfer agents and global networks in the 'transnationalisation' of policy. Journal of European Public Policy, 11(3), 545-566.

Taber, J. (2010, January 29). With one last flight to Haiti, Operation Stork winds down. The Globe and Mail, Retrieved from http://www.theglobeandmail.com/news/politics/ottawanotebook/operation-stork-winds-down/article1450042/

United Nations High Commissioner for Refugees (1951). States Parties to the 1951 Convention relating to the Status of Refugees and the 1967 Protocol. Retrieved 03/13, 2011, from http://www.unher.org/protect/PROTECTION/3b73b0d63.pdf 
United Nations High Commissioner for Refugees (1996) Chile: When we're no longer needed (1 June 1996). Refugee Magazine, 104

United Nations High Commissioner for Refugees. (2010). UNHCR: Global trends 2010.

Geneva, Switzerland: United Nations High Commissioner for Refugees.

United Nations High Commissioner for Refugees. (2011). UNHCR - Crisis in the Horn od

Africa. Retrieved September 01, 2011, from http://www.unher.org/pages/4e1ff4b06.html

United Nations High Commissioner for Refugees. (2011). UNHCR - Nansen refugee award.

Retrieved June 17, 2011, from http://www.unhcr.org/pages/49c3646c461.html

United Nations Office for the Coordination of Humanitarian Affairs (2008). Guiding Principles

on Internal Displacement. Retrieved from http://www.idpguidingprinciples.org/

United Nations University - Institute for Environment and Human Security (2005). 12 October -

UN day for disaster reduction. Retrieved June/17, 2011, from

http://www.ehs.unu.edu/file/get/3916

Warner, K., Earhart, C., Sherbinin, A. d., \& Adamo, S. (2009). In search of shelter: Mapping the effects of climate change on human migration and displacement Care International (CARE).

Warner, K. (2010). Global environmental change and migration: Governance challenges. Global Environmental Change, 20(3), 402.

Wasem, R. E. and Ester, K. (2008). Temporary protected status: Current immigration policy and issues. Federal Publications. Paper 549.

http://digitalcommons.ilr.cornell.edu/key_workplace/549

Wikinson, R. (2001). The environment: A critical time. Refugee Magazine, (127), 13 May 2010. 
Williams, A. (2008). Climate change displacement: Problems and prospects. Metropolis World Bulletin, 8, 20-23.

Williams, A. (2008). Turning the tide: Recognizing climate change refugees in international law. Law \& Policy, 30(4), 502-529.

Yonetani, M. (2011). Displacement due to natural hazard-induced disasters: Global estimates for 2009 and 2010. Geneva: The Internal Displacement Monitoring Centre

(1) BL $-8-110$ 